\title{
Effects of Drug-Induced Reduction in Oxyhemoglobin Affinity on Survival Time of Mice in Severe Hypoxic Conditions
}

\author{
Toyoki Kugimiya, Kunio Suwa, Yutaka Inada, Kiyoshi \\ Mayuzumi* and Toshio Kasama* \\ Department of Anesthesiology, Faculty of Medicine, \\ University of Tokyo, Tokyo 113 and *Research \\ Laboratories, Kodama Co., Ltd., Tokyo 101
}

\begin{abstract}
Kugimiya, T., Suwa, K., Inada, Y., Mayuzumi, K. and Kasama, T. Effects of Drug-Induced Reduction in Oxyhemoglobin Affinity on Survival Time of Mice in Severe Hypoxic Conditions. Tohoku J. exp. Med., 1984, 144 (3), 315-320 — We studied the effect of ortho-iodo sodium benzoate (OISB) given intraperitoneally to mice. $\quad 300$ and $600 \mathrm{mg} / \mathrm{kg}$ of OISB increased P50 from the control value of 41.2 $\mathrm{mmHg}$ to $42.7 \mathrm{mmHg}$ and $45.7 \mathrm{mmHg}$, respectively. The mice were then exposed to two experimental hypoxias, namely, hypobaric hypoxia and carbon monoxide hypoxia. Mean survival time was prolonged from 67.8 (control saline) to $94.8 \mathrm{sec}$ (OISB $300 \mathrm{mg} / \mathrm{kg}$ ) and $112.2 \mathrm{sec}$ (OISB $600 \mathrm{mg} / \mathrm{kg}$ ) in the hypobaric hypoxia, and from $201.3 \mathrm{sec}$ (control saline) to $329.7 \mathrm{sec}$ (OISB $300 \mathrm{mg} / \mathrm{kg}$ ) and $407.7 \mathrm{sec}$ (OISB $600 \mathrm{mg} / \mathrm{kg}$ ) in the carbon monoxide hypoxia. We concluded that OISB had prolonged survival time by reducing oxyhemoglobin affinity, thus facilitating oxygen release in severe hypoxic conditions. —— ortho-iodo sodium benzoate (OISB) ; P50 ; severe hypoxia ; carbon monoxide ; oxyhemoglobin affinity
\end{abstract}

Ortho-iodo sodium benzoate (OISB) was shown to influence the oxygenhemoglobin affinity and the oxygen dissociation curves of both hemoglobin solution and intact red cells (Laver 1975). These effects are also shown to be reversible and dose-dependent.

This interesting property of OISB stimulated many investigators to study physiological consequences of reduced affinity in vitro and in vivo. Litwin et al. (1976) reported in vivo effects of the drug given to intact dogs and showed a significant decrease in oxygen-hemoglobin affinity after single and multiple intravenous administrations, with no apparent detrimental effects except for increases in serum lactate and pyruvate. Our previous study showed that intravenous administration of the drug to intact beagles caused a rightward shift of oxygen dissociation curve, which resulted in increases of $\mathrm{P} 50$ by 1.4 and $1.8 \mathrm{mmHg}$

Received for publication, March 19, 1984. 
depending upon the dosage given, without any apparent ill side-effects to the animals (Kugimiya et al. 1982).

Beneficial effects of reduction in oxyhemoglobin affinity are difficult to define clearly by experiments. Litwin et al. (1977) reported that, with increased P50 by OISB, the compensatory polycythemia, regularly seen when dogs were made hypoxemic, had been prevented. Gross et al. (1977) studied this problem in isolated supported heart preparations and showed beneficial effects of reduced affinity caused by OISB. Teisseire et al. (1979) administered OISB intraperitoneally to rats for 16 weeks. At the end of the period, the animals were exposed to a low inspired oxygen concentration and were subjected to exercise stress. They, however, could not prove significantly increased tolerance to exercise stress in the rat given OISB.

\section{Materials and Methods}

Albino mice, weighing 25 to 35 g, were divided into ten groups according to drugs given and to modes of inducing hypoxia as stated below.

Drugs. We studied the effects of three different drugs on the survival time of the animals under hypoxic conditions. These three drugs and doses are; two doses of OISB : $300 \mathrm{mg} / \mathrm{kg}$ and $600 \mathrm{mg} / \mathrm{kg}$, phenobarbital sodium : $100 \mathrm{mg} / \mathrm{kg}$, and papaverine : $80 \mathrm{mg} / \mathrm{kg}$. All the drugs were dissolved in normal saline to the concentrations that, when given per weight basis, the amount in $\mathrm{ml}$ given was equal to one-hundredth of the body weight in gram of each animal. Normal saline solution alone was injected for the control study.

The drug solutions as well as normal saline solution were administered intraperitoneal-

ly. Hypoxia was induced $30 \mathrm{~min}$ after the injection.

Hypoxic studies. We conducted hypoxic studies under two different conditions, namely, hypobaric hypoxia and carbon monoxide hypoxia.

Hypobaric hypoxia. A chamber system, as shown in the diagram was used (Fig. 1). Animals were placed in chamber A. The pressure of chamber B was reduced to $80 \mathrm{mmHg}$ by a vacuum pump. Stopcock B was closed after the pressure in the chamber B reached the

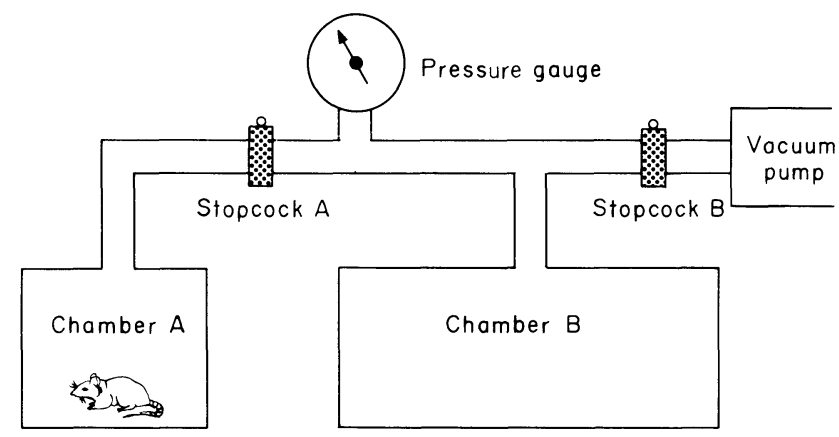

Fig. 1. Schematic illustration of the setup of hypobaric hypoxia experiment. The vacuum pump reduces the pressure in the chamber $\mathrm{B}$ to $80 \mathrm{mmHg}$ while the stopcock $\mathrm{A}$ is closed. After attaining the desired pressure, the stopcock B is closed and the stopcock $\mathrm{A}$ is opened to connect the chambers $\mathrm{A}$ and $\mathrm{B}$. The pressure of the chamber A drops to $180 \mathrm{mmHg}$, and the stopcock $\mathrm{A}$ is closed to continue the experiment. 
desired level. Another stopcock A, which had been closed while the pressure in the chamber $\mathrm{B}$ was reduced, was opened so as to connect the chambers A and B. As the capacities of the chambers $\mathrm{A}$ and $\mathrm{B}$ were constructed in a ratio of 1 to 5.8 , the pressure in the chamber A would drop to $180 \mathrm{mmHg}$, which was monitored by a pressure gauge. The calculated $\mathrm{PO}_{2}$ in the chamber A would be $37.8 \mathrm{mmHg}$. Each group consisted of 10 animals in this hypoxic study.

Carbon monoxide hypoxia. With mice in the air-tight chamber, carbon monoxide gas was flushed into it until the concentration of the gas reached $1.6 \%$. Carbon monoxide concentration was monitored by an infrared analyzer, (Riken Co., Tokyo, Model RI-55A.). Each group consisted of 15 animals in this hypoxic study.

Observation. We measured the time required for the animals to cease spontaneous respiratory movement (terminal gasp) after the pressure was dropped or after carbon monoxide was introduced into the chamber.

Affinity measurement. The blood samples for oxyhemoglobin dissociation curves were obtained from the different set of animals, which were given the same treatment as stated above. They were, however, not exposed to hypoxic conditions. Each group consisted of six animals. $30 \mathrm{~min}$ after the drugs were injected intraperitoneally, blood samples were taken into heparinized syringes from the blood vessels of the neck immediately after the animals were sacrificed by dislocation of the cervical spine. P50's were obtained by drawing oxyhemoglobin dissociation curves with Hem-O-Scan (Aminco). Blood gas measurement was also performed with the same blood sample by ABL-2 (Radiometer). The results of blood gas analysis were used in the calculation of P50's to the standard condition. Standardization of the measured P50's was calculated according to the formula we published before (Kugimiya et al. 1979).

All statistical analyses were performed by Student's $t$-test.

\section{Results}

\section{Hypobaric hypoxia}

Survival time was $67.8 \pm 4.2 \mathrm{sec}$ in the control mice group, $94.8 \pm 7.2 \mathrm{sec}$ in the OISB $300 \mathrm{mg} / \mathrm{kg}$ group, $112.2 \pm 12.6 \mathrm{sec}$ in the OISB $600 \mathrm{mg} / \mathrm{kg}$ group, $240.0 \pm 48.6$ sec in the phenobarbital Na $100 \mathrm{mg} / \mathrm{kg}$ group and $220.8 \pm 38.4 \mathrm{sec}$ in the papaverine $80 \mathrm{mg} / \mathrm{kg}$ group. (Table 1). Statistical analysis revealed significant differences between the control group and the other four groups.

TABLE 1. Hypobaric hypoxia

\begin{tabular}{lc}
\hline \multicolumn{1}{c}{ Group } & Survival time $(\mathrm{sec})$ \\
\hline Control saline & $67.8 \pm 4.2$ \\
OISB $300 \mathrm{mg} / \mathrm{kg}$ & $94.8 \pm 7.2^{*}$ \\
OISB $600 \mathrm{mg} / \mathrm{kg}$ & $112.2 \pm 12.6^{*}$ \\
Phenobarbital Na & $240.0 \pm 48.6^{*}$ \\
$100 \mathrm{mg} / \mathrm{kg}$ & $220.8 \pm 38.4^{*}$ \\
Papaverine $80 \mathrm{mg} / \mathrm{kg}$ & \\
\hline
\end{tabular}

Mean \pm S.E. $\quad n=10$.

* Significantly different from the control saline group. 
TABLE 2. Carbon monoxide hypoxia

\begin{tabular}{lc}
\hline \multicolumn{1}{c}{ Group } & Survival time $(\mathrm{sec})$ \\
\hline Control saline & $201.3 \pm 15.5$ \\
OISB $300 \mathrm{mg} / \mathrm{kg}$ & $329.7 \pm 60.3^{*}$ \\
OISB $600 \mathrm{mg} / \mathrm{kg}$ & $407.7 \pm 81.6^{*}$ \\
Pheobarbital Na & $899.3 \pm 95.2^{*}$ \\
$\quad 100 \mathrm{mg} / \mathrm{kg}$ & $430.7 \pm 59.1^{*}$ \\
Papaverine $80 \mathrm{mg} / \mathrm{kg}$ & \\
\hline
\end{tabular}

Mean \pm S.D. $n=15$.

* Significantly different from the control saline group.

TABLE 3. Blood gas analysis

\begin{tabular}{lccccc}
\hline & $\begin{array}{c}\text { Control } \\
\text { saline }\end{array}$ & $\begin{array}{c}\text { OISB } \\
300 \mathrm{mg} / \mathrm{kg}\end{array}$ & $\begin{array}{c}\text { OISB } \\
600 \mathrm{mg} / \mathrm{kg}\end{array}$ & $\begin{array}{c}\text { Phenobarbital Na } \\
100 \mathrm{mg} / \mathrm{kg}\end{array}$ & $\begin{array}{c}\text { Papaverine } \\
80 \mathrm{mg} / \mathrm{kg}\end{array}$ \\
\hline $\mathrm{P} 50(\mathrm{mmHg})$ & $41.2 \pm 1.7$ & $42.7 \pm 1.3^{*}$ & $45.7 \pm 1.8^{*}$ & $41.1 \pm 2.0$ & $40.7 \pm 1.4$ \\
$\mathrm{pH}$ & $7.10 \pm 0.10$ & $7.15 \pm 0.08$ & $7.10 \pm 0.12$ & $7.24 \pm 0.04^{*}$ & $7.18 \pm 0.04$ \\
$\mathrm{PCO}_{2}(\mathrm{mmHg})$ & $50 \pm 6$ & $48 \pm 11$ & $54 \pm 14$ & $50 \pm 4$ & $55 \pm 14$ \\
$\mathrm{PO}_{2}(\mathrm{mmHg})$ & $55 \pm 21$ & $43 \pm 7$ & $54 \pm 10$ & $43 \pm 8$ & $67 \pm 42$ \\
$\mathrm{BE}(\mathrm{mEq} / \mathrm{liter})$ & $-16.8 \pm 5.9$ & $-14.1 \pm 4.2$ & $-15.9 \pm 4.3$ & $-7.3 \pm 4.0^{*}$ & $-10.0 \pm 5.1$ \\
$\mathrm{Hb}(\mathrm{g} / 100 \mathrm{ml})$ & $19.5 \pm 0.8$ & $19.0 \pm 2.0$ & $19.0 \pm 0.9$ & $17.6 \pm 0.9^{*}$ & $18.0 \pm 1.5$ \\
\hline \multicolumn{5}{c}{ Mean \pm S.D. } & $n=6$. \\
& * Significantly different from the control saline group.
\end{tabular}

\section{Carbon monoxide hypoxia}

Survival time was $201.3 \pm 15.5 \mathrm{sec}$ in the control group, $329.7 \pm 60.3 \mathrm{sec}$ in the OISB $300 \mathrm{mg} / \mathrm{kg}, 407.7 \pm 81.6 \mathrm{sec}$ in the OISB $600 \mathrm{mg} / \mathrm{kg}, 899.3 \pm 95.2 \mathrm{sec}$ in the phenobarbital Na $100 \mathrm{mg} / \mathrm{kg}$ group and $430.7 \pm 59.1 \mathrm{sec}$ in the papaverine $80 \mathrm{mg} /$ $\mathrm{kg}$ group. (Table 2). Statistical analysis also revealed significant differences between the control group and the other four groups.

\section{Blood gas analysis}

The results of blood gas analysis on venous blood are shown in Table 3 . In the phenobarbital group, $\mathrm{pH}, \mathrm{BE}$ and $\mathrm{Hb}$ showed statistically significant differences from the control group. In any other groups, blood gas analysis revealed no significant differences from the control values.

\section{Affinity}

P50 of the control group was $41.2 \pm 1.7 \mathrm{mmHg}$. That of the OISB $300 \mathrm{mg} / \mathrm{kg}$ group was $42.7 \pm 1.3 \mathrm{mmHg}$ and OISB $600 \mathrm{mg} / \mathrm{kg} 45.7 \pm 1.8 \mathrm{mmHg}$. These two values showed statistically significant differences from the control value. P50 of the phenobarbital $\mathrm{Na}$ group was $41.1 \pm 2.0 \mathrm{mmHg}$ and that of the papaverine 
group was $40.7 \pm 1.4 \mathrm{mmHg}$, neither of which differed significantly from the control.

\section{Discussion}

Our results showed that OISB had an effect which prolonged the survival time of mice in two experimentally produced extremely hypoxic conditions. In the hypobaric hypoxic condition, $\mathrm{PaO}_{2}$ decreased sharply to a level which was below the $\mathrm{PvO}_{2}$ of the mice before the hypoxia was induced. The saturation must have been lower than $50 \%$, because our measured $\mathrm{P} 50$ in the control mice group was $41 \mathrm{mmHg}$ and the calculated $\mathrm{PO}_{2}$ in the hypoxic chamber was about 38 $\mathrm{mmHg}$. Unless acclimatized slowly, such a reduction in $\mathrm{PO}_{2}$ is lethal to the animals. In addition to an acute reduction in ambient $\mathrm{PO}_{2}$, further precipitous decrease in $\mathrm{PO}_{2}$ continued to a level at which the animals could no longer sustain their life.

Deleterious effects of reduced oxygen-hemoglobin affinity in small animals with high metabolic rates can be true only when animals are exposed to moderately hypoxic conditions (Turek et al. 1973), where the reduced oxygen binding capacity at the lungs is expected to have significant effect on the availability of oxygen to the tissues. In an extremely hypoxic conditions, however, this would no longer be a factor to affect survivability. Oxygen available in blood should be fully utilized to maintain life. Reduction of affinity produced by OISB and, adding to this, by acute $\mathrm{pH}$ changes due to an increased rate of anaerobic metabolism under hypoxia, was likely to have contributed to prolong the survival time of these animals. Whether the effects of OISB and acidosis are synergic in reducing $\mathrm{P} 50$ is unknown.

Carbon monoxide binds with hemoglobin very readily and strongly, thus competing with oxygen, and tissue hypoxia ensues. With $1.6 \%$ of $\mathrm{CO}$ in the air, resulting in $\mathrm{PCO}$ of about $12 \mathrm{mmHg}$, almost all hemoglobin would be turned into carboxyhemoglobin in a very short period. It is also well known that, under carbon monoxide poisoning, hemoglobin remaining unbound with carbon monoxide binds with oxygen more strongly and, therefore, results in the increased affinity.

These two factors led to severe tissue hypoxia promptly and resulted in the death of the control group mice in 201 sec. The prolongation of survival time in OISB-treated mice must be again due to the decreased oxygen-hemoglobin affinity produced by OISB. OISB may be viewed as squeezing oxygen out of these oxygen storage tightly bound with remaining normal hemoglobin.

As oxygen availability at the lungs was not a problem in this experiment, physically solved oxygen in the plasma was also available to tissues. Although it did not sustain life very long, the survival time in this experiment group was longer than hypobaric hypoxia group generally.

The effect of phenobarbital on survival time in our experiments of hypoxic 
conditions was much more pronounced than that of OISB. The mechanisms for life-prolonging effect must be different from OISB. Barbiturates are well known to protect the brain from global hypoxia (Steen and Michenfelder 1979). This effect obviously must have taken place in our results. With decreased metabolic rate produced by phenobarbital $\mathrm{Na}$, which is expressed in our study by significantly higher $\mathrm{pH}$ and lower base deficit in this group, the animals could endure extremely hypoxic conditions longer than other groups and, hence, longer breathing activity. We were surprised to see the papaverin prolonged survivability of mice. Papaverin is known to dilate vessels (Cook and James 1981). Whether this effect or other unknown ones have any place to have beneficial effects in hypoxic conditions is open to question.

\section{References}

1) Cook, P. \& James, I. (1981) Drug therapy: Cerebral vasodilators. New Engl. J. Med., 305, 1508-1513.

2) Gross, G.J., Warltier, D.C. \& Hardman, H.F. (1977) Effect of ortho-iodo sodium benzoate on hemoglobin-oxygen affinity in normal and ischemic myocardium. $J$. Pharmacol. exp. Ther., 203, 72-81.

3) Kugimiya, T., Suwa, K. \& Yamamura, H. (1979) P50 values of Japanese adults by venous blood sampling. Resp. Circulat., 26, 143-147. (Japanese)

4) Kugimiya, T., Fujisawa, M., Suwa, K., Yamamura, H., Minohara, K. \& Kasama, T. (1982) Effects of ortho-iodo sodium benzoate (OISB) on oxygen-hemoglobin affinity and its relation to plasma concentrations in dogs. Tohoku J. exp. Med., 136, 35-41.

5) Laver, M.B. (1975) Oxygen Measurements in Biology and Medicine, Butterworth, London-Boston, pp. 5-22.

6) Litwin, S.B., Skogen, W.F., McCreadie, S.R. \& Laver, M.B. (1976) Sodium oiodobenzoate and hemoglobin-oxygen affinity: in vivo effect. J.appl. Physiol., 41, 900-904.

7) Litwin, S.B., Skogen, W.F. \& Laver, M.B. (1977) Effect of sodium orthoiodobenzoate on oxygen transport and erythropoiesis in hypoxemic dogs with a right-to-left cardiac shunt. Surgery, 81, 633-639.

8) Steen, P.A. \& Michenfelder, J.D. (1979) Barbiturate protection in tolerant and nontolerant hypoxic mice: Comparison with hypothermic protection. Anestho siology, 50, 404-408.

9) Teisseire, B.P., Soulard, C.D., Herigault, R.A., Leclerc, L.F. \& Laver, M.B. (1979) Effects of chronic changes in hemoglobin- $\mathrm{O}_{2}$ affinity in rats. J. appl. Physiol., 46, 816-822.

10) Turek, Z., Kreuzer, F. \& Hoofd, L.J.C. (1973) Advantage or disadvantage of a decrease of blood oxygen affinity for tissue oxygen supply at hypoxia: A theoretical study comparing man and rat. Pflügers Arch., 342, 185-197. 